\title{
Morphological aspects of epididymal microscopy and rete testis in greater Rhea americana
}

\author{
Breno Nahuel Freneau ${ }^{1}$ (D) Saulo Fernandes Mano de Carvalho ${ }^{1}$ (D) \\ Simone Maria Teixeira de Sabóia-Morais ${ }^{2}$ (D) Gustavo Eduardo Freneau ${ }^{*}$
}

${ }^{1}$ Laboratório de Andrologia e Tecnologia do Sêmen, Escola de Veterinária e Zootecnia, Universidade Federal de Goiás (UFG), 74001-970, Goiânia, GO, Brasil. E-mail: gfreneau@gmail.com. *Corresponding author.

${ }^{2}$ Departamento de Morfologia, Instituto de Ciências Biológicas, Universidade Federal de Goiás (UFG), Goiânia, GO, Brasil.

\begin{abstract}
The purpose of this research was to study the histology and describe the microscopy findings of the epididymis epithelium of greater Rhea americana at three time periods: November $2005(n=14)$, December $2006(n=20)$, and May 2007 ( $n=20)$, to observe and compare the differences that occurred. We studied the epididymis from 54 rheas, bred in Santa Maria, Rio Grande do Sul, Brazil. The epididymis were collected during commercial slaughter and fixed in bouin. Optical microscopy was used to measure the cellular structure, types of cells, tubules, and stereological values like the epididymis epithelium diameters, lumen, thickness, and relative volume of the tissue structure. Additionally, electron microscopy was studied. In December 2006 and May 2007, the means of the epididymis tubular diameter were: 79.1 and $58.1 \mu \mathrm{m}$, epithelium thickness: 24.0 and $52.2 \mu \mathrm{m}$, and lumen diameter: 55.0 and $5.8 \mu \mathrm{m}$, respectively. Regarding the volumetric proportion, we reported the following values: epithelium volume 36.2 and $80.4 \%$, lumen without spermatozoon 19.6 and $3.0 \%$, lumen with spermatozoon 5.4 and $0.0 \%$, interstitium 35.4 and $12.0 \%$, blood vessels 3.5 and $4.6 \%$, structures in cellular superficies 1.4 and $0 \%$, lamina 1.4 and $3.2 \%$, and artifacts 0.3 and $1.3 \%$, respectively. The epididymis ducts had a circular form in transverse sections with spermatozoon only in November 2005 and December 2006. The Rhea's epididymis morphology was found to be similar to ostriches, roosters, and Japanese quail. Here, we present data from stereological microscopy (tubular diameter, epithelium thickness, and lumen diameter), volumetric proportion (epithelium, lumen without spermatozoon, lumen with spermatozoon, interstitium, blood vessels, structures in cellular superficies; cilium, estereocilium, and lamina) in this species during the repose and sexual activity period (reproductive season).
\end{abstract}

Key words: epididymis diameter; epididymis tubule; ratites; birds reproduction; seasonality; volumetric proportion.

Aspectos morfológicos da microscopia do epitélio do epidídimo

da Rhea americana

RESUMO: $O$ objetivo desta pesquisa foi estudar a histologia e descrever os achados microscópicos do epitélio epididimo de ema em três periodos: novembro/2005 $(n=14)$, dezembro/2006 $(n=20)$ e maio/2007 $(n=20)$, para observação e comparação das diferenças que ocorreram nesses tempos distintos. Estudamos o epidídimo de 54 animais, criados em Santa Maria, RS. Durante o abate comercial, os epididimos foram coletados e fixados em Bouin. A microscopia óptica mede a estrutura celular, tipos de células, túbulos e valores estereológicos, como os diâmetros do epitélio do epidídimo, lúmen, espessura, volume relativo da estrutura do tecido. Em dezembro/2006 e maio/2007, as médias do

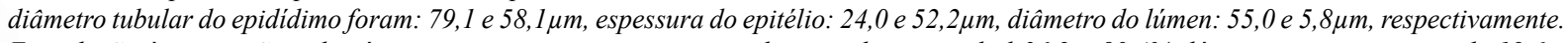
Em relação à proporção volumétrica, encontramos os seguintes valores: volume epitelial 36,2 e 80,4\%, lúmen sem espermatozoide 19,6 e 3,0\%, lúmen com espermatozoide 5,4 e 0,0\%, intestínio 35,4 e 12,0\%, vasos sanguíneos 3,5 e 4,6\%, estruturas celulares superficies 1,4 e 0\%, lâmina 1,4 e 3,2\%, artefatos 0,3 e 1,3\%, respectivamente. Os ductos do epididimo apresentaram forma circular em cortes transversais com espermatozoide apenas em novembro/2005 e dezembro/2006. A morfologia do epididimo de Rhea foi semelhante ao avestruz, galo e codornas japonesas. Apresentamos dados de microscopia estereológica (diâmetro tubular, espessura do epitélio, diâmetro do lúmen), proporção volumétrica, em porcentagem (epitélio, lúmen sem espermatozóide, lúmen com espermatozoide, intestório, vasos sanguíneos, estruturas em superfícies celulares - cilio - estereocílio, lâmina e artefatos) nesta espécie nos períodos de repouso e atividade sexual (estação reprodutiva). Palavras-chave: diâmetro e Epidídimo, túbulo epididimário, ratitas, reprodução aves, sazonalidade, proporção volumétrica.

\section{INTRODUCTION}

Epididymal morphology knowledge helps in understanding the reproduction of a determined species and spermatozoid maturity. The epididymis has not been studied in the Greater Rhea. Differences between the epididymis of Galliformes and Anseriformes have been reported (BAKST, 1980), 
demonstrating that the epididymis is not the same in all bird species. Many authors have affirmed that, in domestic birds such as roosters, ducks, quail, and ostriches, the epididymides had some similarities. However, there were also some differences, for instance, cellular types that form in the epididymal duct (TINGARI, 1971; BUDRAS \& SAUER, 1975; HESS et al., 1976; HESS \& THURSTON, 1977; AIRE, 1979; AIRE et 1., 1979; AIRE, 1980; BUDRAS AND MEIER, 1981; AIRE, 1982a; AIRE, 1982b). As yet, the epididymis of the Rhea americana has not yet been studied with microscopic morphology. This research aimed to study the morphology and describe the microscopy findings of the Greater Rhea's epididymis at three distinct periods of the year. We intend to provide reference subsidies for other researches, assisting in the understanding of spermatozoid maturation and its relationship to the fertility of the Rhea americana.

\section{MATERIALS AND METHODS}

\section{Location and animals}

Fifty-four sexually mature Greater Rheas, with an average age of $2.5 \pm 0.5$ years and an average bodyweight of $30.12 \pm 1.87 \mathrm{~kg}$, derived from a commercial breeding ranch and slaughtered in a slaughterhouse credentialed by the Federal Inspection Service (SIF) were used. We made three collections, in November $2005(n=14)$, December $2006(n=20)$ and May $2007(n=20)$. The climate data from when the samples were taken are presented in table 1 . The animals came from a single breeding ranch located in the county of Santa Maria, Rio Grande do Sul, Brazil. Two defined seasons were observed (dry and cold; and wet and hot). Climate data can be reviewed in more detail in FRENEAU et al. (2016). All animals were subjected to equal handling and were fed commercial pelleted rations that contained the following: calcium (max.) $1.8 \%$, ethereal extract (min.) $2 \%$, phosphorus (min.) $0.65 \%$, fibrous material (max.) $12 \%$, mineral material (max.) 16\%, raw protein (min.) 16\%, humidity (max.) 13\%. The company possessed a Commercial Breeder License, IBAMA Registry $\mathrm{n}^{\circ}$ 652515. IBAMA provided the Research License $058 / 2005$ for this study.

\section{Collection, tissue preparation, light microscopy, and stereological parameters}

During commercial slaughter, samples from the cranial, medial, and caudal portions of the epididymides were collected. Samples were cut into cubic shapes about $1 \mathrm{~cm}^{3}$ in size, immersed in Bouin for 12 hours, washed in running water, and placed in $70^{\circ} \mathrm{GL}$ of alcohol. Then, they were transported to the laboratory and processed. Sections were dehydrated in serial alcohol, diafanized in serial xilol, embedded in paraffin, and sliced into 4 $\mu \mathrm{m}$ thick microtomes. The sections were stained in hematoxylin and eosin (LUNA, 1968). Sections from ten animals of each collection were also stained with Masson's Trichrome so that the collagen fibers could be visualized. We identified the rete testis, proximal efferent tubules, distal efferent tubules, connecting tubules, and epididymal tubule, with its cellular types and structures in the cellular surface such as cilia and stereocilia. We measured the diameter of the epididymal tubule, luminal diameter, and epithelial thickness. These measurements were estimated from the averages of ten tubules from each section and five sections from each animal. Therefore, there were 50 measurements taken for each epididymis. The cranial, medial, and caudal portions were randomly distributed during mensuration in such a way that the five sections were selected at random. We utilized only circular shaped epididymal tubule parts. Tubular and luminal diameters and epithelial thickness were measured under a binocular microscope at 40x. This was done by tracing two lines, one vertical and one horizontal, forming a $90^{\circ}$ angle as proposed

Table 1 - Average, maximum, and minimum values of temperature, humidity and radiation during the collection periods.

\begin{tabular}{|c|c|c|c|c|c|c|c|c|c|}
\hline & \multicolumn{3}{|c|}{---------Temperature $\left(\mathrm{C}^{\circ}\right)$--------- } & \multicolumn{3}{|c|}{-----------Humidity (\%)----------- } & \multicolumn{3}{|c|}{---------Radiation $\left(\mathrm{KJm}^{2}\right)$--------- } \\
\hline & avg & $\max$ & $\min$ & avg & $\max$ & $\min$ & avg & $\max$ & $\min$ \\
\hline November 2005 & 21.8 & 28.6 & 15.6 & 76.0 & 78.5 & 73.5 & 1139.8 & 3715 & 0,0 \\
\hline December 2006 & 25.1 & 31.2 & 19.5 & 74.3 & 79.5 & 73.1 & 1058.7 & 3802 & 0,0 \\
\hline May 2007 & 14.7 & 19.7 & 9.3 & 54.0 & 57.1 & 52.0 & 658.1 & 2249 & 0,0 \\
\hline
\end{tabular}

Source: Meteorological Station of Santa Maria - National Meteorology Institute (INMET). 
by WEIBEL et al. (1966). Axio Vision ${ }^{\circledR}$ version 3.0.6 sp4 (Carl Zeiss, GmbH) was used for these measurements. The volumetric proportion of the epididymal structures accounted for the following observations: epithelium, lumen without and with spermatozoa inside, conjunctive tissues, blood vessels, structures of the cellular surface (cilia and stereocilia), and lamina propria. They were measured using the point-counting technique with the support of an eyepiece graticule with equidistant points Carl Zeiss KLP8x/18 ${ }^{\circledR}, 400 x$, and percentage expressions. Some proportions consisted of the sum of structures, such as the volumetric proportion of the epididymal duct, which was the sum of the lumen, the epithelium and structures of the cellular surface, and the lamina propria. The interstitial tissue was the sum of the conjunctive tissue and blood vessels. The number of volumetric proportion measurements was made by counting 1000 points for each dish and recording the relative points of each studied item.

\section{Transmission electron microscopy}

In December 2006 and May 2007, samples were collected for electron microscopy. The testicles of two males from each of the seasonal timepoints were picked at random to be used. After the collection, the tissues were sliced in fragments about $1 \mathrm{~mm}^{3}$ in size and immersed in glutaraldehyde at $1 \%$ tamponade in sodium phosphate $0.1 \mathrm{M}, \mathrm{pH} 7.2$ for $2 \mathrm{~h}$. After this, the fixative was discarded, the pieces were carefully washed with distilled water, postfixated with $2 \%$ osmium tetroxide for $2 \mathrm{~h}$, washed again with distilled water, and then immersed in $70 \%$ alcohol and transported to the laboratory. Then, the sections underwent increasing series of alcohol and acetone included in Epon 812 resin. The blocks were transported to the laboratory, sliced in 0.5 $\mu \mathrm{m}$ ultramicrotomes, and then sliced into ultrathin sections, $60 \mathrm{~nm}$ thick and contrasted with $2 \%$ uranyl acetate and $2 \%$ lead citrate for 5 minutes. Then, they were analyzed using a Carl Zeiss transmission electron microscope. Photographs were taken and revealed through traditional techniques.

\section{Statistical analysis}

We calculated the mean and standard deviations of the microscopic epididymal measurements (tubular diameter, epithelial height, and luminal diameter) from the three collections, as well as the measurements of the studied volumetric proportion (epithelium, lumen without spermatozoa, lumen with spermatozoa, conjunctive tissue, blood vessels, structures of the cellular surface, lamina propria, technique artifacts, epididymal tubule, and interstitial tissue). The means obtained from the collections were compared through a variance analysis (Tukey, $\mathrm{P}<0.05$ ). We utilized the procedures, Proc Means, and Proc GLM from the SAS statistical package (SAS, 1997).

\section{RESULTS AND DISCUSSION}

The epididymis of the Rhea americana is formed posteriorly to the rete testis, the proximal efferent ducts, the distal efferent ducts, the connecting ducts, and the epididymal ducts (Figure 1).

The seminiferous tubules lead directly to the Rete testis, and the proximal efferent ducts connect the Rete testis and the epididymal duct. In the transition between the Rete testis and the epididymis, we observed that areas are mainly separated by fibrous connective tissue and collagen fibers (Figure 2). Macroscopically, some ducts of the Rete testis are present inside the tunica albuginea, next to the testicle, and others are present in the extra-testicular region, next to the epididymis. Most of the Rete testis were observed in the portion next to the epididymis, which has many ducts longitudinally connected, forming cisterns that are linked to the efferent tubules, between the ducts. There was a large amount of conjunctive tissue with collagen fibers that were longitudinal (Figure 2).

The epithelium of the Rete testis presented with a cuboidal shape and pseudo-stratification with nonciliated cells (Figure 3). Its cells were also well visible, compared to other studies, such as in ducks (AIRE, 1982). The literature also mentioned that the epithelium of the Rete testis is pseudostratified in most birds; although, in ostriches, it is a simple epithelium (AIRE \& SOLEY, 2003). In this regard, the Greater Rhea is similar to most birds.

The proximal efferent ducts possess a simple cuboidal epithelium, with ciliated and nonciliated cells (Figure 4). These tubules have cells with elongated nuclei in the horizontal plane, occupying the basal portion of the cytoplasm (Figure 4). The apical surfaces of nonciliated cells presented an amorphous substance.

The structure of the luminal surface of the efferent ducts had a high concentration of cilia. These are related to the transportation and reabsorption of fluids, in which the spermatozoa are suspended. This was also reported by AIRE \& SOLEY (2001) in ostriches. According to CLULOW \& JONES (1982, 1988), approximately $86 \%$ of the fluid that enters the epididymis proceeding the testicle would be reabsorbed in the proximal efferent ducts of quail. The 


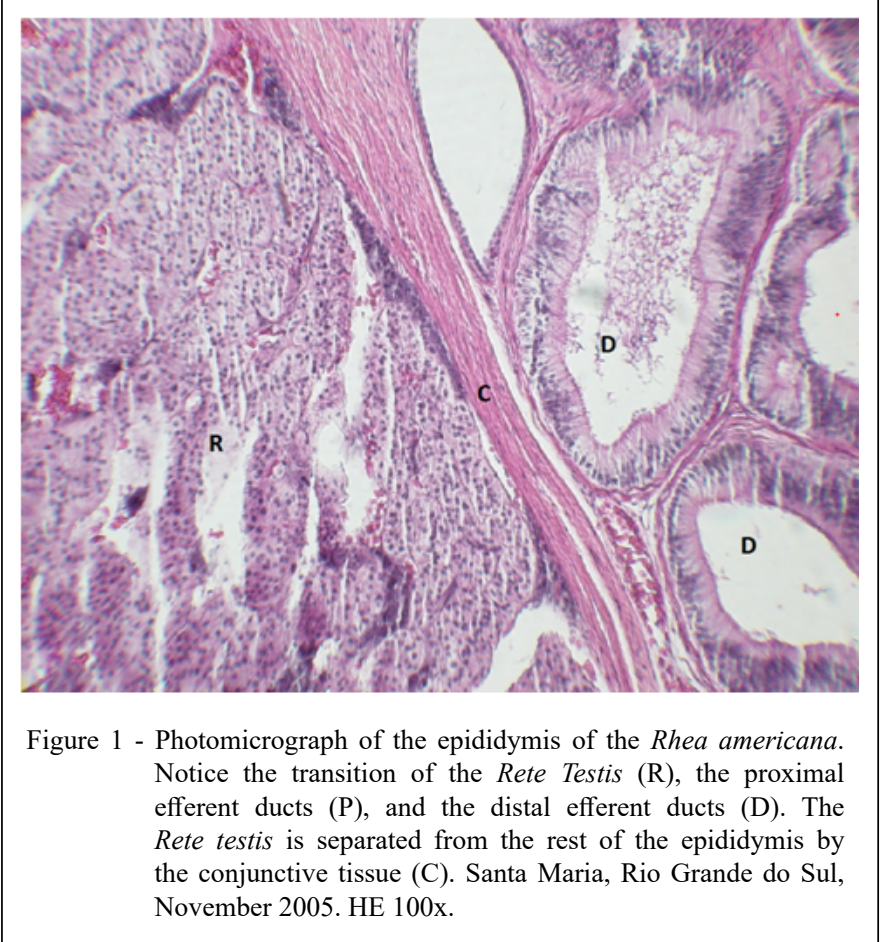

structure of these ducts in the Greater Rhea is similar to quail, with many ciliated cells, and nonciliated cells among them. AIRE (1982a, 1982b) asserts that these cells are responsible for the reabsorption of luminal fluids, and named them "Type I" cells. In the Rhea americana, the proximal efferent ducts possessed ciliated and non ciliated cells.

The distal efferent ducts had a pseudostratified epithelium with cilia (Figures 5, 6 , and 7). The sections of these ducts exhibited a

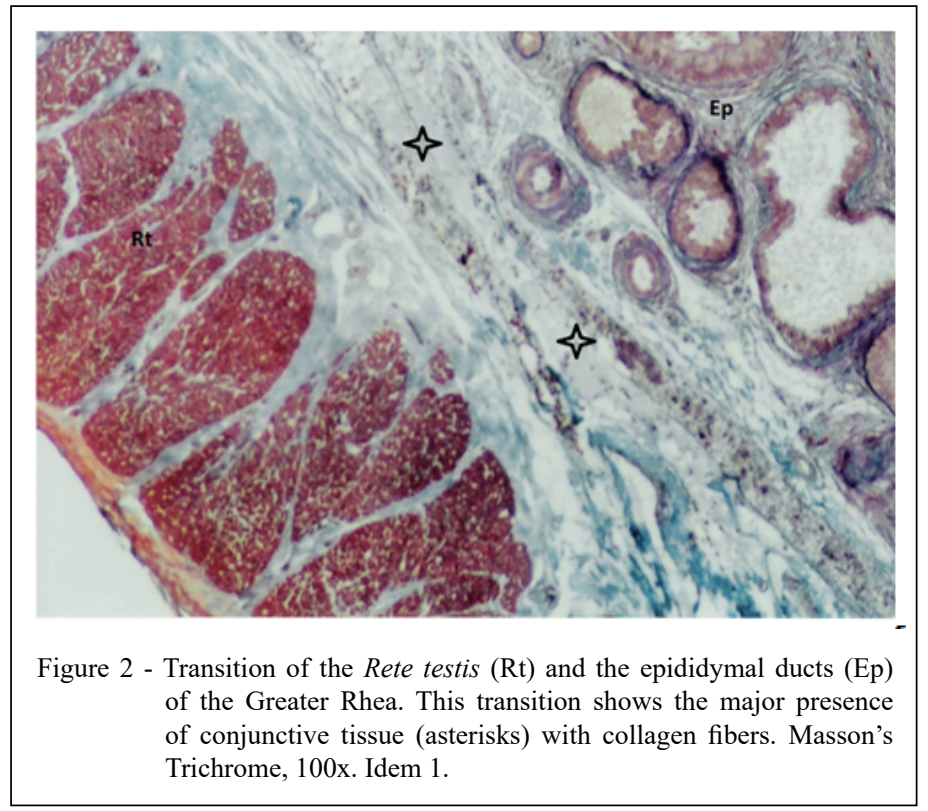

Ciência Rural, v.51, n.7, 2021. 


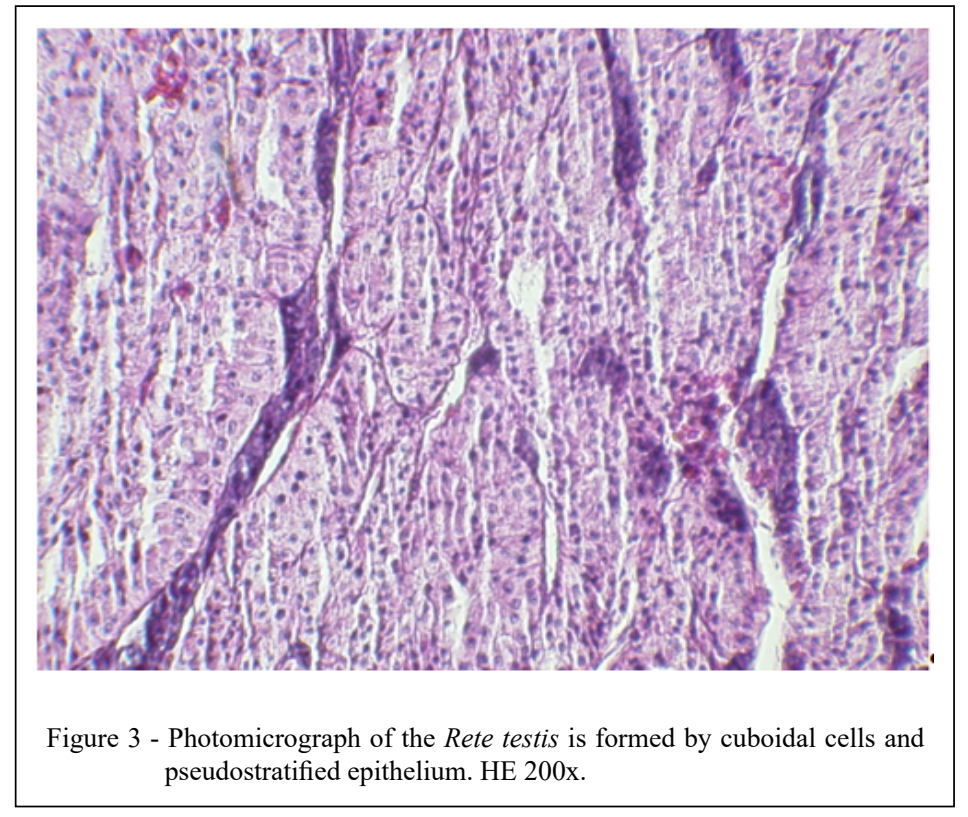

more homogenous epithelial structure than in the proximal efferent ducts. This epithelium consisted of cellular pseudo-stratification with the predominance of ciliated cells. We observed the accumulation of spermatozoa in its lumen (Figure 5).
An amorphous substance was encountered in the cellular surface of the efferent ducts, especially in the nonciliated cells (Figure 5). This was also reported by BAKST (1980), in chickens and turkeys, and by TINGARI (1971) in a transmission electron

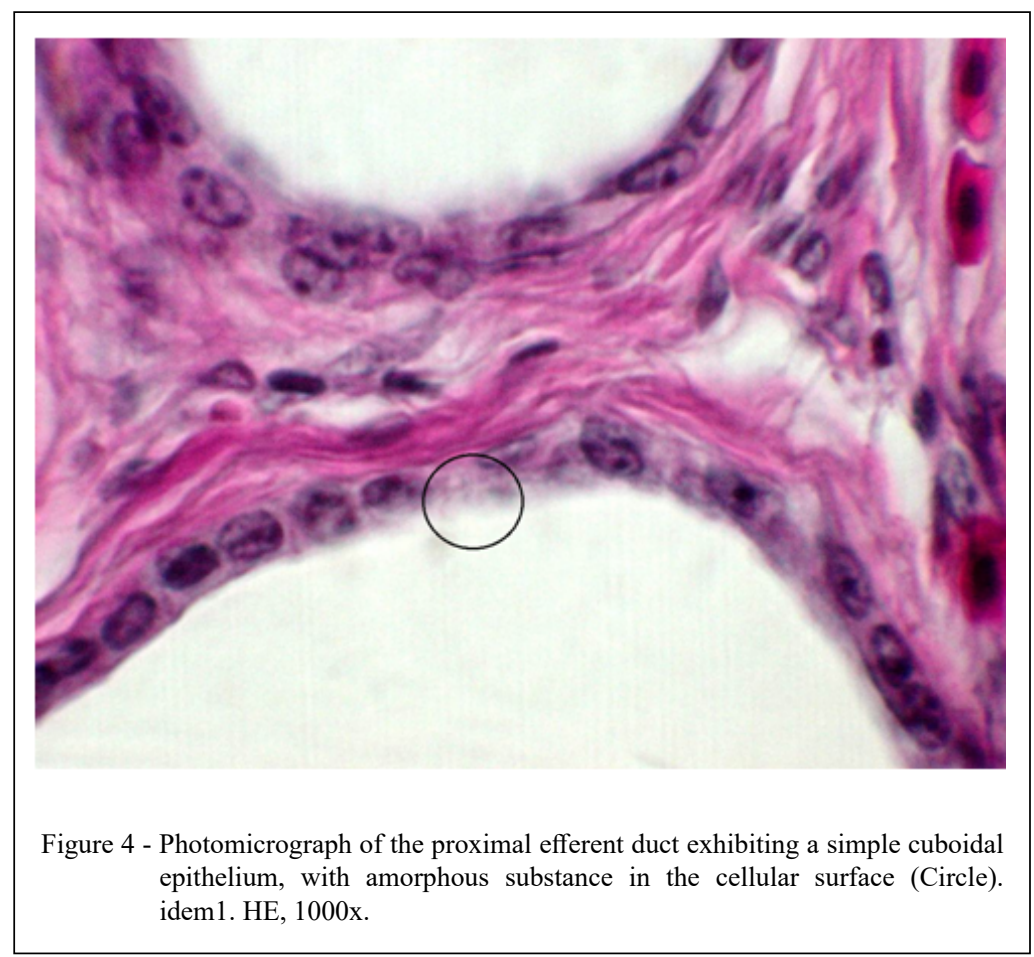

Ciência Rural, v.51, n.7, 2021. 


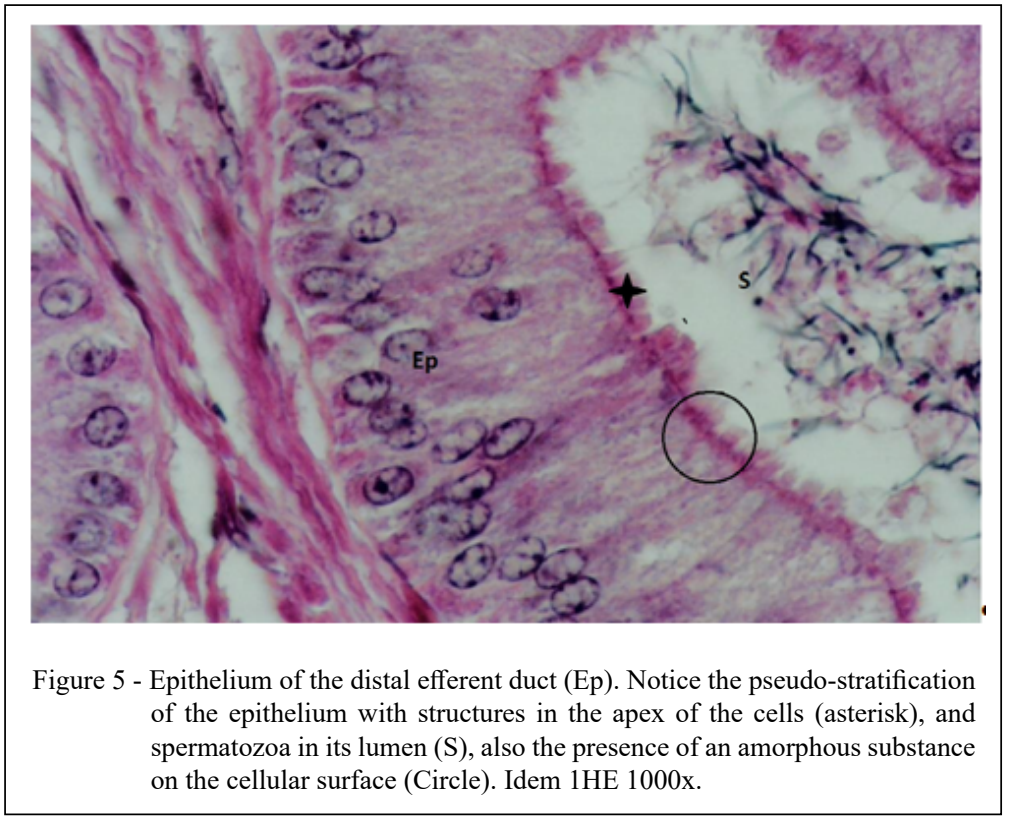

microscopy study of roosters and turkeys. However, AIRE et al. (1979) and $\operatorname{AIRE}(1979,1980)$, considered these apical structures as cellular distortions and fixation technique artifacts. The epididymal duct possesses a pseudostratified epithelium with ciliated (stereocilia) and nonciliated cells (Figure 6).
The epididymal duct was composed of the epithelium with pseudostratified column cells and stereocilia (Figure 8). There were also non ciliated cells, but in low numbers and the cilia were less dense than the ones encountered in the distal efferent ducts (Figure 5).

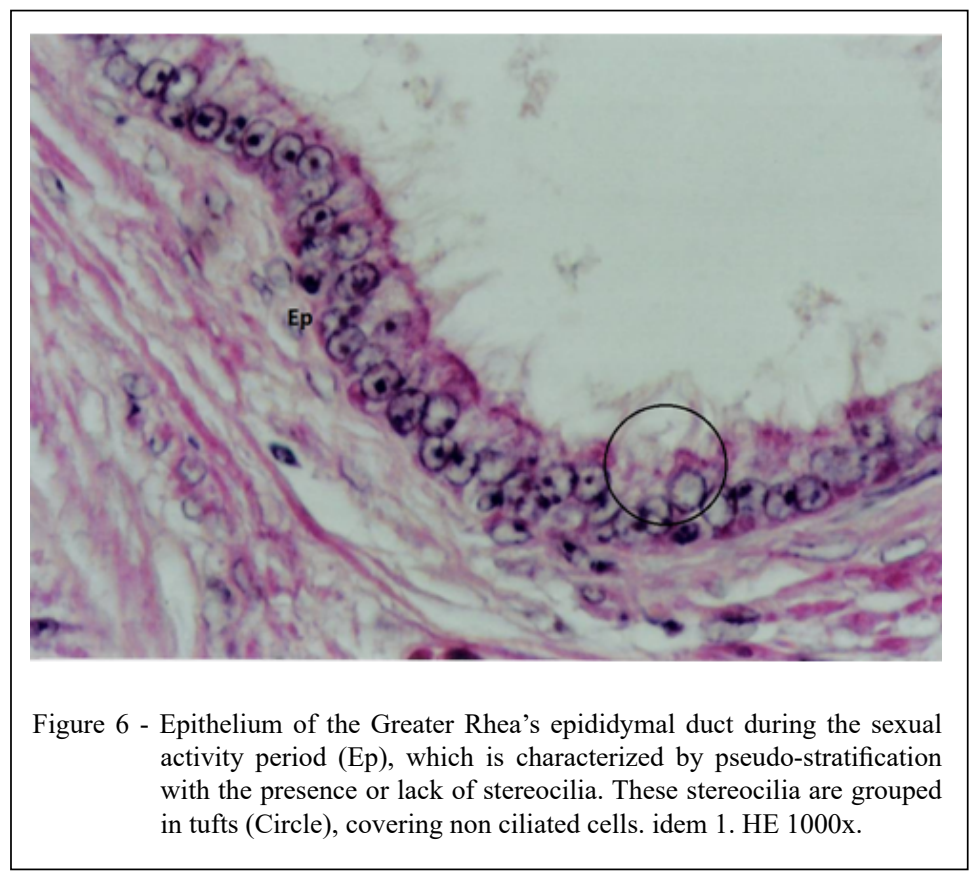

Ciência Rural, v.51, n.7, 2021. 


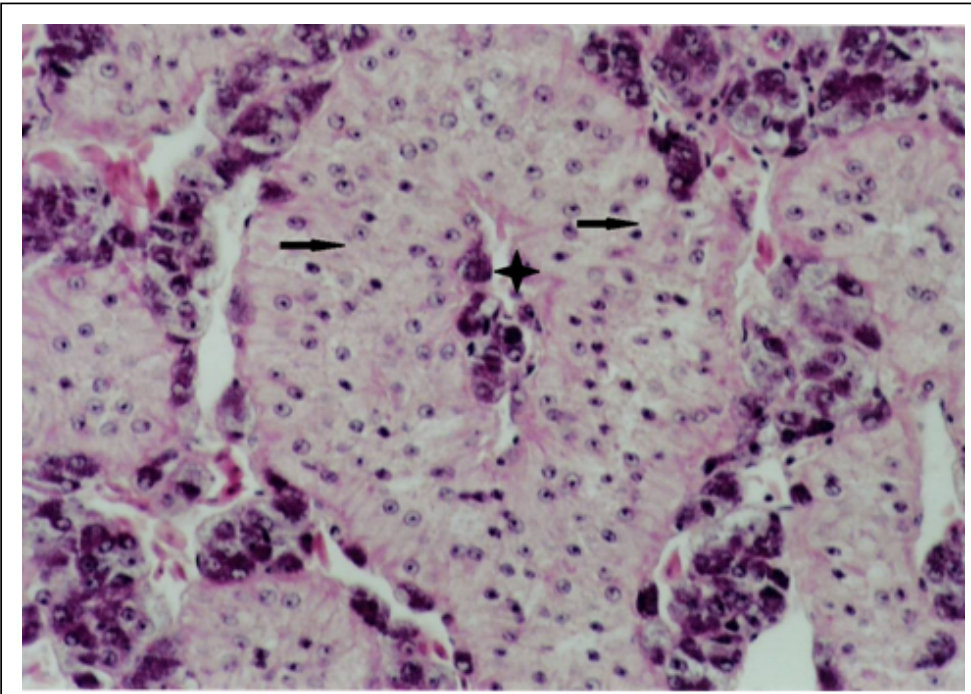

Figure 7 - Photomicrograph of the epididymal ducts of the Greater Rhea during sexual repose. Notice that the lumen is very narrow (asterisks). Cells present clear and round nuclei and condensed chromatin (arrows idem 1. HE 400x.

The adopted nomenclature for the epididymal duct and its cells in the Greater Rhea has been proposed by BUDRAS \& SAUER (1975), AIRE et al. (1979), AIRE (1982a, b), and AIRE \& SOLEY (2001). After studying domestic roosters and turkeys,
BAKST (1980), could not describe the structures of the cellular surface of the epididymal tubule. In the studies mentioned, vascular perfusion was used as the fixation method. This is different from the current study (immersion), which may explain the

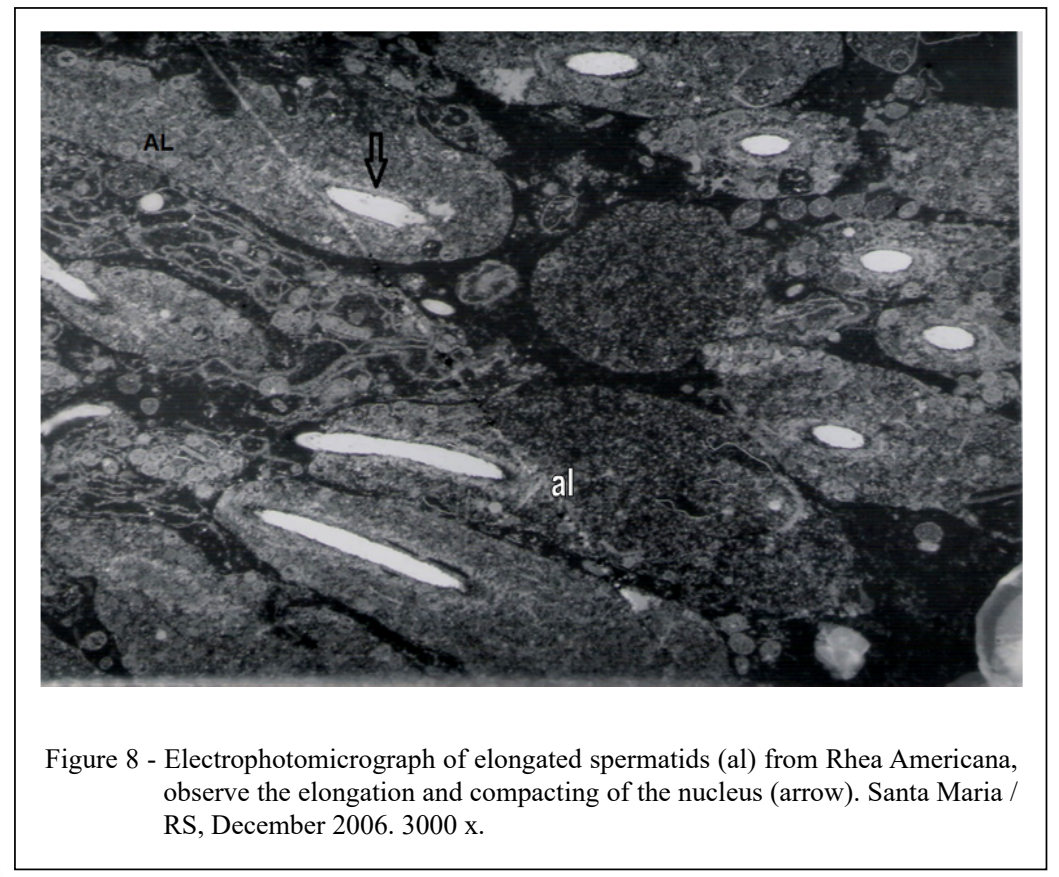

Ciência Rural, v.51, n.7, 2021. 
differences observed. AIRE \& SOLEY (2000) also opted for immersion during a study of ostriches and managed to observe the cells of the rete testis and the apical cellular structures of the epididymal duct.

Using optical microscopy to compare the sections from the spring-summer (November 2005 and December 2006; Figures 5 and 8 ) to the sections from autumn-winter (MAY 2007; Figure 7), vast qualitative morphological differences were observed. In May 2007, there was no presence of cellular activity, the epididymal ducts had almost no or very narrow lumen, and there were no spermatozoa.

Notably, it was impossible to differentiate between duct types. As previously described, the epithelium, presented with a single pattern, stratification, clear and round nuclei, and condensed chromatin. There were no structures in the apical cellular region, cilia, and stereocilia. In the May 2007 collection, the conjunctive tissue appeared to be thicker (Figure 9). Data regarding the epididymal tubule measurements from the three collections are presented in table 2 .

Larger epididymal ducts with thicker epitheliums and evident lumen $(<0.05)$ were observed in the November and December collections as compared to May (Table 2). This demonstrated reproductive seasonality in Greater Rhea under the conditions researched. LEITE \& CODENOTTI (2005) reported that in the Rio Grande do Sul, the reproductive period of Greater Rhea, happens in spring and summer. Sexual hormones in both sexes were reported in two different seasons (VALDEZ et al. 2014). These reports are in agreement with the 2005 and 2006 collections. Contrastingly, the May 2007 collection was characterized as sexual repose.

The luminal diameters of the tubules in the samples from November 2005 and December 2006 measured 56.3 and $55 \mu \mathrm{m}$, respectively. In a study about microscopic epididymal structure in domestic roosters, TINGARI (1971) reported that the luminal diameter of the epididymal duct varied between 100 and $500 \mu \mathrm{m}$, which are well above the values encountered in Greater Rhea. No reference values were found for ostriches and emu in the literature. In Greater Rhea, we observed that epithelial height in the November 2005 and December 2006 collections measured 24.6 and $24.0 \mu \mathrm{m}$, respectively. In the rooster, these values were between 10 and $26 \mu \mathrm{m}$, showing the similarities between the two birds. STEFANINI et al. (2000) reported that the tubular diameter, luminal diameter, and epithelial height of domestic doves (Columba livia) were $197.62 \mu \mathrm{m}$,

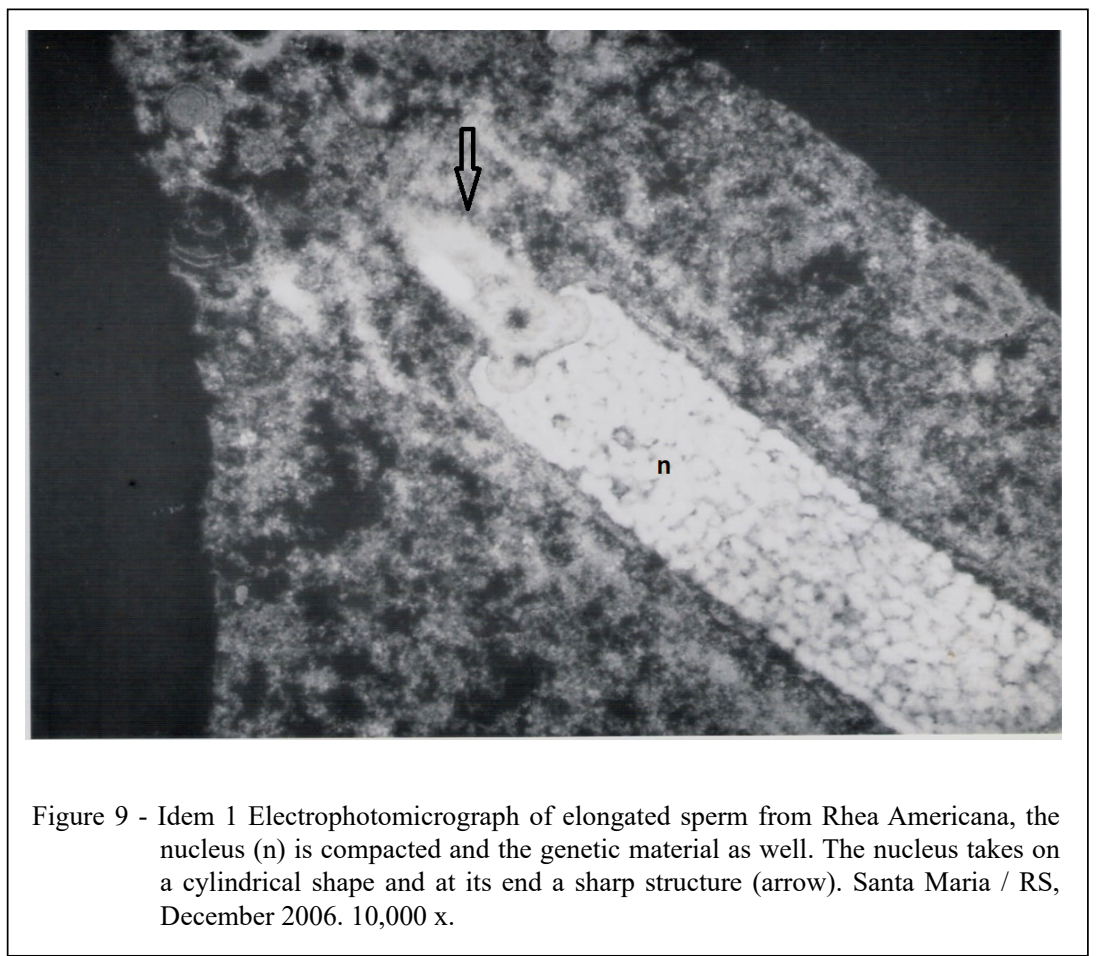

Ciência Rural, v.51, n.7, 2021. 
Table 2 - Microscopic measurements and volumetric proportions $(\mathrm{x} \pm \mathrm{dp})$ of the epididymal tissue in Greater rhea. Collections made in November 2005, December 2006 and May 2007, Santa Maria, Rio Grande do Sul.

\begin{tabular}{lcrr}
\hline Measurements $(\mu)$ & November 2005 & December 2006 & May 2007 \\
\hline Vertical duct diameter & $89.8 \pm 23.1 \mathrm{a}$ & $83.8 \pm 9.6 \mathrm{a}$ & $62.5 \pm 4.8 \mathrm{~b}$ \\
\hline Horizontal duct diameter & $72.0 \pm 16.8 \mathrm{a}$ & $74.4 \pm 8.1 \mathrm{a}$ & $53.6 \pm 8.5 \mathrm{~b}$ \\
\hline Duct diameter & $80.9 \pm 20.0 \mathrm{a}$ & $79.1 \pm 8.8 \mathrm{a}$ & $58.1 \pm 6.6 \mathrm{~b}$ \\
\hline Vertical luminal diameter & $61.9 \pm 17.3 \mathrm{a}$ & $58.5 \pm 8.4 \mathrm{a}$ & $5.5 \pm 0.1 \mathrm{~b}$ \\
\hline Horizontal luminal diameter & $50.6 \pm 13.6 \mathrm{a}$ & $51.6 \pm 8.6 \mathrm{a}$ & $6.1 \pm 0.3 \mathrm{~b}$ \\
\hline Luminal diameter & $56.3 \pm 15.0 \mathrm{a}$ & $55.0 \pm 8.5 \mathrm{a}$ & $5.8 \pm 0.2 \mathrm{~b}$ \\
\hline Vertical epithelial height & $27.8 \pm 7.3 \mathrm{~b}$ & $25.3 \pm 6.2 \mathrm{~b}$ & $57 \pm 4.7 \mathrm{a}$ \\
\hline Horizontal epithelial height & $21.3 \pm 6.0 \mathrm{~b}$ & $22.8 \pm 5.5 \mathrm{~b}$ & $47.4 \pm 8.6 \mathrm{a}$ \\
\hline Epithelial height & $24.6 \pm 6.1 \mathrm{~b}$ & $24.0 \pm 5.0 \mathrm{~b}$ & $52.2 \pm 5.6 \mathrm{a}$ \\
\hline
\end{tabular}

Different letters in the same line indicate statistical difference $\mathrm{P}<0.05$ (Tukey).

$147.49 \mu \mathrm{m}$, and $25.16 \mu \mathrm{m}$, respectively. The epithelial height was similar to the Greater Rhea with the other values being larger.

Data regarding the volumetric proportions of the three collections are displayed in table 3. In the May 2007 collection, the volumetric proportions of the epididymal tubule increased $(\mathrm{P}<0.05$, Table 3 ), and the luminal ones decreased $(\mathrm{P}<0.05)$. No spermatozoa were encountered in the lumen during this period.

In the May 2007 collection, there was little lumen present in the sections. However, the epithelial height was proportionally larger due to the diminished lumen (Tables 2 and 3). AIRE (2007) asserted that the volumetric proportion of the conjunctive tissue and the blood vessels in ostriches epididymis during sexual activity and repose were 58.2 and $1.8 \mu \mathrm{m}$, respectively. These values are similar to those seen in the current study with Greater Rhea. During the collections of November 2005 and December 2006, the Greater Rheas underwent a period of sexual activity, the data from the authors discussed above were also from animals during sexual activity.

Observing the elongated spermatids in transmission electron microscopy, it was noticed that during the formation of the spermatozoid, the genetic material compacted into a large and electron-dense chromatin granule form, with the nucleus assuming a cylindrical shape that was narrow and long (Figure 8). It was also noticed in the extremity of the genetic

Table 3 - Volumetric proportions of the epididymal tubules in the Greater Rhea ( \pm dp). Collections made in November 2005, December 2006 and May 2007, Santa Maria, Rio Grande do Sul.

\begin{tabular}{|c|c|c|c|}
\hline Volumetric Proportion (\%) & November 2005 & December 2006 & May 2007 \\
\hline Epididymal epithelium & $33.6 \pm 6.6 \mathrm{~b}$ & $36.2 \pm 3.6 \mathrm{~b}$ & $80.3 \pm 1.9 \mathrm{a}$ \\
\hline Lumen without spermatozoid & $23.5 \pm 7.9 \mathrm{a}$ & $19.6 \pm 4.9 \mathrm{~b}$ & $3.0 \pm 0.0 \mathrm{c}$ \\
\hline Lumen with spermatozoid & $4.9 \pm 7.9 \mathrm{~b}$ & $5.4 \pm 4.9 \mathrm{a}$ & $0.0 \pm 0.0$ \\
\hline Structures of the cellular surf. & $1.4 \pm 0.4 \mathrm{a}$ & $1.4 \pm 0.4 \mathrm{a}$ & $0.0 \pm 0.0$ \\
\hline Lamina propria & $0.5 \pm 0.4 \mathrm{c}$ & $1.4 \pm 0.7 \mathrm{~b}$ & $3.2 \pm 0.7 \mathrm{a}$ \\
\hline Epididymal duct & $64.0 \pm 6.9 \mathrm{~b}$ & $64.1 \pm 3.6 \mathrm{~b}$ & $86.6 \pm 1.5 \mathrm{a}$ \\
\hline Conjunctive tissue & $32.7 \pm 7.1 \mathrm{a}$ & $31.8 \pm 5.3 \mathrm{a}$ & $7.4 \pm 1.0 \mathrm{~b}$ \\
\hline Blood vessels & $2.8 \pm 0.5 \mathrm{c}$ & $3.5 \pm 0.8 \mathrm{~b}$ & $4.5 \pm 0.8 \mathrm{a}$ \\
\hline Interstitial tissue & $35.5 \pm 7.1 \mathrm{a}$ & $35.4 \pm 5.0 \mathrm{a}$ & $12.0 \pm 0.8 \mathrm{~b}$ \\
\hline Artifacts & $0.3 \pm 0.4 \mathrm{~b}$ & $0.3 \pm 0.4 \mathrm{~b}$ & $1.3 \pm 1.0 \mathrm{a}$ \\
\hline
\end{tabular}

Different letters in the same line indicate statistical difference $\mathrm{P}<0.05$ (Tukey). 
material, opposite the flagellum, a structure of acute form located in the sub-acrosomal space that occupied almost all of the compacted genetic material width (Figure 9). As they are transformed into spermatozoids, the elongated spermatids became narrower and longer in shape. The spermatozoids in the tubular lumen are very narrow, the width of their head is very similar to the width of their flagellum, and because of this in smaller zooms, it was difficult to visualize their acrosome and the correct definition of the transition between the head and the beginning of the intermediary piece.

During spermiogenesis, the round spermatid suffers morphological alterations originating in the spermatozoid. In non-Passeriformes birds, these transformations are divided into twelve steps and can be observed in quail (LIN AND JONES, 1990) and turkeys (AIRE, 2003).

During the tenth step, the acrosome is well-formed and accommodates an acute structure in the subacrosomal space called perforatorium. Together, the acrosome and the perforatorium have been related as acrosomic complex (BACCETTI, 1979). The perforatorium is a fibrous structure composed of parallel actin filaments (BACCETTI et al., 1980; CAMPANELLA et al., 1979). This structure has the function of sustaining the acrosome and has been reported in many non-Passeriformes birds: in domestic roosters (BAKST \& HOWARTH, 1975; LAKE et al., 1968; THURSTON \& HESS, 1987) garganey (MARETTA, 1975) and ostriches (BACCETTI et al., 1991; SOLEY, 1993).The perforatorium of the acrosome was also observed in this study (Figure 9). It presented similarities to what was described by the authors above.

There were no difficulties in fixating and staining the histological sections of the Greater Rhea. Some authors have mentioned difficulties in the fixation of sections from quail, roosters and helmeted guinea fowl (AIRE, 1982a; AIRE, 1982b, 1980, 1979; AIRE et al., 1979; BUDRAS \& SAUER, 1975; GUNAWARDANA \& SCOTT, 1977; HESS et al., 1976; HESS \& THURSTON, 1976; LAKE, 1971; MIKAMI et al., 1988; NAGANO, 1962).

Microscopic epididymal measurements (duct diameters, epithelial height, luminal diameter) of the Greater Rhea and volumetric proportion measurements (epithelium, lumen without spermatozoa, lumen with spermatozoa, conjunctive tissue, blood vessels, structures of the cellular surface, cilia, stereocilia, lamina propria, epididymal duct, and interstice) were observed and displayed larger dimensions during the spring, demonstrating sexual activity. The luminal surface contained different structures that began in the Rete testis, passed through the proximal and distal efferent ducts, and reached the connecting and epididymal ducts.

We presented epididymal characteristics of the Greater Rhea. The transition between the periods of sexual activity and repose was the most apparent in the epididymal epithelium. During the sexual activity period, the epithelium was exuberant and showed noticeable signs of activity. During the repose period, it was not possible to differentiate between cellular types, and whenever the lumen was not diminished, its opening was insignificant.

Acknowledgements.- To Ireny Rodrigues de Almeida and Jacir Antônio Dalla Vecchia, from Associação Brasileira dos Criadores de Emas (ABRACE), allowing the use of animal samples and data. To Prof Dr. Marcelo Emílio Beletti do Departamento de Biologia Celular, Instituto de Ciências Biomédicas da Universidade Federal de Uberlândia pelo suporte na microscopia eletrônica de transmissão.

\section{ACKNOWLEDGEMENTS}

To Ireny Rodrigues de Almeida and Jacir Antônio Dalla Vecchia, from Associação Brasileira dos Criadores de Emas (ABRACE), allowing the use of animal samples and data. To Prof Dr. Marcelo Emílio Beletti do Departamento de Biologia Celular, Instituto de Ciências Biomédicas da Universidade Federal de Uberlândia pelo suporte na microscopia eletrônica de transmissão. Coordenação de Aperfeiçoamento de Pessoal de Nível Superior (CAPES), Brasil.

\section{DECLARATION OF CONFLICT OF INTEREST}

The authors declare no conflict of interest. The founding sponsors had no role in the design of the study; in the collection, analyses, or interpretation of data; in the writing of the manuscript, and in the decision to publish the results.

\section{AUTHORS' CONTRIBUTIONS}

All authors contributed equally for the conception and writing of the manuscript. All authors critically revised the manuscript and approved of the final version.

\section{REFERENCES}

AIRE, T. A., The epididymal region of Japanese quail (Coturnix coturnix japonica). Acta anatomica, v.103, p.305312, Basel, 1979.

AIRE, T. A., The ductulli efferentes of the epididymal region of birds. Journal of Anatomy, v.130, p.707-723, London, 1980.

AIRE, T. A., The rete testis of birds. Journal of Anatomy, v.135, p.97-110, London, 1982a. 
AIRE, T. A., Surface morphology of the ducts of the epididymal region of the drake (Anas platyrhynchos) as revealed by scanning and transmission electron microscopy. Journal of Anatomy, v. 135, p. 513-520, Londonm 1982b.

AIRE, T. A., Phylogeny, morphology and fertilization. In: Aire, T. A. Reproductive biology and phylogeny of birds. Enfield Jersey, Plymouth, chap. 2, p.37-113, 2007.

AIRE, T. A.; et al., The structure of excurrent ducts of the testis of the Guinea fowl (Numida meleagridis). Journal of Anatomy, v.129, p.633-643, London, 1979.

AIRE, T. A.; SOLEY, J. T., The surface features of epithelial lining of the ducts of the epididymis of the ostrich (Struthio camelus). Anatomia, Histologia, Embryologia, v.29, p.119-126, Berlin, 2001. Available from: $<$ https://doi.org/10.1046/j.1439-0264.2000.00247.x >.

AIRE, T. A.; SOLEY, J. T., The morphological features of the rete testis of the ostrich (Struthio camelus). Anatomy and Embryology, Berlin, v.207, p.355-361, 2003. doi: 10.1007/s00429-003-0347-0.

BAKST, M. R., Luminal topography of the male chicken and turkey excurrent ducts system. Scanning Electron Microscopy, v.3, p.419-425, Chicago, 1980.

BUDRAS, K. D.; MEIER, U., The epididymis and its development in ratite birds (ostrich, meu, rhea). Anatomy and Embryology, Berlin, v.162, p.281- 299, 1981

BUDRAS, K. D.; SAUER, T., Morphology of the epididymis of the cock (Gallus domesticus) and its effect upon the steroid sex hormone synthesis. I. Ontogenesis, morphology and distribution of the epididymis. Anatomy and Embryology, v.148, p.175-196, Berlin, 1975.

CLULOW, J.; JONES, R. C., Production, transport, maturation, storage and survival of spermatoa in the male Japanese quail, Coturnix coturnix. Journal of Reproduction and Fertility, v.64, p.259-266, Cambridge, 1982.
CLULOW, J.; JONES, R. C., Studies on fluid and spermatozoal in the extratesticular genital ducts of the Japanese quail. Journal of Anatomy, v.157, p.1-11, London, 1988.

FRENEAU, G.E.; et al, Aspects of spermatogenesis and microscopic testicular morphology in Greater Rhea, Rhea americana (Linnaeus, 1758). Pesq. Vet. Bras. v.36, n.10, p.10451052, 2016. doi: 10.1590/S0100-736X2016001000019.

HESS, R. A.; THURSTON, R. J., Ultrastructure of the epithelial cells in the epididymal region of the turkey (Meleagris gallopavo). Journal of Anatomy, v.124, p.765-778, London, 1977.

HESS, R. A.; et al.. Morphology of epididymal region and ductus deferens of the turkey (Meleagris gallopavo). Journal of Anatomy, v.122, p.241-252, London, 1976.

LEITE, M. A. S.; CODENOTTI, T. L., Comportamento parental de machos da ema Rhea americana (Linnaeus, 1758), em Ambiente Natural, no Rio Grande do Sul. Revista de Etologia, v.7, n.1, p.43 - 47, São Paulo, 2005.

LUNA, L. G., Manual of histologic staining methods of the armed forces institute of pathology. 3.ed. McGraw-Hill Book, p. 258, New York, 1968.

SAS INSTITUTE. SAS/STAT User's Guide 8.0. Cary: SAS Institute, 1997.

STEFANINI, M. A.; et al., Estrutura do ducto epididimário do pombo doméstico (Columba livia). Naturalia, v.25, p.11-21, São Paulo, 2000.

TINGARI, M. D., On the structure of the epididymal region and ductus deferens of the domestic fowl (Gallus domesticus). Journal of Anatomy, v.109, p.423-435, London, 1971.

VALDEZ, D.J.,et al., 2014. Seasonal changes in plasma levels of sex hormones in the Greater Rhea (Rhea americana), a South American Ratite with a complex mating system. PLoS ONE, 9(5): e97334. doi: 10.1371/journal. pone.0097334.

WEIBEL, E. R et al., Practical stereological methods for morphometric cytology. Journal of Cell Biology, v.30, p.23-38, New York, 1966. 